\title{
Race and Gender in the Contestation and Resistance of Teacher Authority and School Sanctions: The Case of African Caribbean Pupils in England
}

\author{
CECLLE URICHT AND DEBBIE WEEKES
}

\section{Introduction}

Pupit resistance withim schools has lomg been theorized and debated within the sociology of education. Theories on the relationship between pupil and school have historically argued that schools are quite clearly implicated in the reproduction of social divisions, but they have been criticized for suggesting that schoos could not make a difference to the creation of inequanties among pupils." Thus, resistance theorics have cmerged in response to the often deterministic anafyses embedded within social reproduction theories and have looked at the possibility of schools creating agents who can, through various forms of cultural resistance, effect changes within oppressive social strtctures. ${ }^{2}$ The tension between structure and agency that such work has caused has avoided the determinism that results from giving social structures a form of intentional rationality. Instead resistance theory has looked at the limits of these structures through an examination of the agency of disadvantaged pupiss who reject what educational institutions have to offer. However, resistance theories themselves have anso been the subject of theoretical and empirical criticism since the mid $1980 \mathrm{~s}$, much of which has focused on their gendered romanticizing of working-class mate youth and the theories' failure to examine the areas where class-specific forms of resistance intersect with social relations of race, gender, and sexuality." Early

The niane of the schools and locat area, logether with these of the children and ecaters, fuave all been changed to ensure anonymity. In this article, "black" is used ass a political term to denote those of African Carbbean heritage only.

'Samuel Bowles and Herbert Cintis, Shooting in Cafpitatist America (London: Routledge \& Kegan Patal, 1976); Mark NeFadden, "Resistance to Schexhing and Fducationat Outcomes: Que stions of Struc-

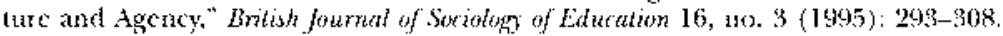

${ }^{2}$ pierre Bourdiet, "What Makes a Social (atss? On the Theoretical and Practical lexistence of

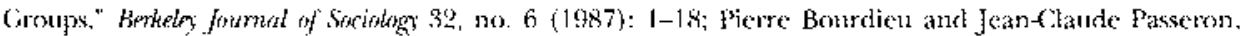

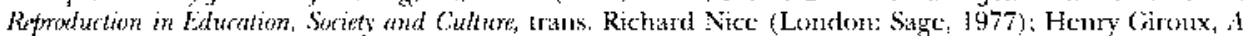

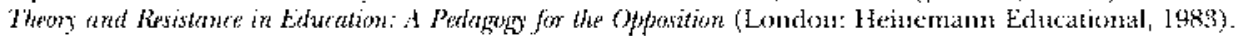

"Angeda McRobbic, "Working (Aass (Girls and the Cuture of Femininity," in Women Take /ssue: Aspurts of Women's Subardination, edl. Women's Sudy Group (Jondon: Hutchinson, 1978), pp. 96-104: lan Watson, "Education, Class and Cuttere: The Birmingham Ethoggraphic Fradition and the Problem

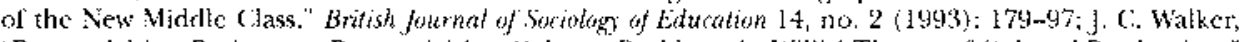
"Romanticising Resistance. Romantic sing (ulture: Problems in Willis" Theory of ( Aultural Production,"

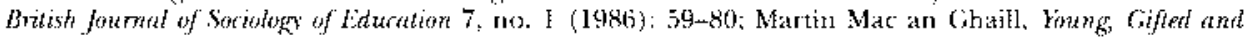

Comprorative Elucation Reviere, vol. 47, 110. 1 .

(1) 200'3 by the Comparatise and International Education Society All rights reserved.

$0010-4086 / 2003 / 4701-00002505.00$ 
resistance theories therefore focused on class domination. There was little that addressed resistance against other forms of inequality.

In view of these criticisms there has been an increasing body of work conducted by feminists on gendered forms of resistance and the implications of these for masculine and feminine identities, and by other researchers on the resistances of black pupils in schools. ${ }^{4}$ Much of this work, however, has itself been subject to theoretical and methodological criticism, which has moved the debate on race and gender within education beyond the sphere of schooling and into wider discussions as to the nature of institutionalized sexism and racism. ${ }^{5}$

In this article, we will argue that the theorizing of pupil behavior within the areas of resistance or contestation continues to be theoretically important despite the problems that beset the definition of all forms of oppositional behavior in schools as resistant and the inadequacy of some theories of resistance to provide strategies for change. ${ }^{6}$ Based on a study of school exclusions in one large education authority, we will explore the responses to schooling of black pupils in order to explore the relevance of theorizing pupil resistance particularly in relation to the experience of school exclusion. Though much research has explored the processes through which black pupils resist the state educational process, ${ }^{7}$ the relationship between racialized strategies of resisting teacher authority, and the power embedded within the sanction of school exclusion, remain unexplored.

Thus, in this article, we will explore whether the sanction of school exclusion reflects the relationship between pupil as resister-contester on one hand and the powers held by schools to exclude and the powers of teachers to employ school sanctions as a response to pupil resistance on the other. Through interrogating notions of resistance in relation to the racialized po-

Black (Milton Keynes, England: Open University Press, 1988), and The Making of Men: Masculinity of Sexualities and Schooling (Buckingham: Open University Press, 1995).

${ }^{4}$ Lynn Davies, Pupil Power: Deviance and Gender in Education (London: Falmer, 1984); Jean Anyon, "Intersections of Gender and Class: Accommodation and Resistance by Working Class and Affluent Females to Contradictory Sex-Roles Ideologies," in Gender, Class and Education, ed. Len Barton and Stephen Walker (London: Falmer, 1983), pp. 60-75; S. Riddell, "Pupils, Resistance and Gender Codes: A Study of Classroom Encounters," Gender and Education 1, no. 2 (1989): 183-97; Mac an Ghaill, Young, Gifted and Black; David Gillborn, Race, Ethnicity and Education: Teaching and Leaming in Multi-Ethnic Schools (London: Unwin Hyman, 1990); Tony Sewell, Black Masculinities and Schooling: How Black Boys Survive Modern Schooling (Stoke on Trent: Trentham, 1997); Cecile Wright, John Eggleston, David Dunn, and Madju Anjali, Education for Some: The Educational Vocational Experiences of 15-18 Year Old Members of Minority Ethnic Groups (Stoke on Trent: Trentham, 1985); Cecile Wright, "The Relations between Teachers and Afro-Caribbean Pupils: Observing Multi-Racial Classrooms," in Gender under Scrutiny: New Inquiries in Education, ed. Gaby Weiner and Madeleine Arnot (London: Hutchinson, 1987), pp. 163-70.

${ }^{5}$ Martin Hammersley and Roger Gomm, "A Response to Gillborn and Drew on Race, Class and School Effects," New Community 19, no. 2 (1993): 348-53; Peter Foster, Roger Gomm, and Martin Hammersley, Constructing Educational Inequality (London: Falmer, 1996).

${ }^{6}$ A. Brittan and M. Maynard, Sexism, Racism and Oppression (Oxford: Blackwell, 1984); Deborah Gerwirz, "Analyses of Racism and Sexism in Education and Strategies for Change," British Joumal of Sociology of Education 12, no. 2 (1991): 183-201.

${ }^{7}$ Mac an Ghaill, Young, Gifted and Black; Ernest Cashmore and Barry Troyna, eds. Black Youth in Crisis (London: Allen \& Unwin, 1982). 
sitions of black pupils and those excluded, and their often conflictual relationships with teachers and schools, we will examine whether racializing the concept of resistance within the context of school exclusion can adequately reflect the experiences of black children who are both included in and excluded from their education institution.

\section{The Study}

This article draws on data gathered as part of a much broader ethnographic study of school exclusions conducted in five secondary schools in a large local education authority in the Midlands. The aim of the research was to explore and document the nature and pattern of secondary school exclusions of pupils from ethnic groups and identify the school processes that may lead to the exclusion of black pupils from school. The research was also concerned with exploring the nature of educational provisions for black male pupils permanently excluded from mainstream schooling in view of the disproportionate exclusions of these pupils from schools both nationally and locally. The research involved surveying all secondary schools in the county education authority within which the study was situated in order to assess the pattern of exclusions within the area. Additionally, extensive interviews were conducted within five secondary schools in the education authority and with twelve black male pupils who had experienced permanent exclusion from school, together with their parents or caregivers. Those pupils were referred to us by a local community organization that had advocated on their behalf in the exclusion proceedings. This article addresses the issues arising from these interviews.

The five schools within which the bulk of the research was conducted varied according to local authority status and pupil intake. One school had recently acquired government-funded status because of its falling rolls, another was a fairly new school with a technology bias, while the remaining three were under local authority control. The schools were primarily selected in relation to the proportion of their pupils who were from ethnic backgrounds. Schools with low, average, and higher-than-average proportions of black pupils were selected in order to explore whether different school processes that lead to the exclusion of black children from school relate to the numbers of black children attending.

School A was situated in the middle of a fairly wealthy suburb in the city and performed very well within the area of the education authority in terms of the General Certificate of Secondary Education (GCSE) higher-level grades obtained. The majority of the pupil population was drawn from the immediate area, and therefore many of the pupils came from professional families. There was a small but increasing black population both in the area and the school. School A was under local authority control. School B was situated near a fairly large low-income housing estate in the center of the city. It would take excluded 
pupils from a nearby technology school and had a greater number of black pupils than school A. There was also a greater focus on race illustrated by displays on the walls. School B was under local authority control.

School $\mathrm{C}$ was situated in an area with high unemployment and a large black population. The area was also in receipt of central government special funding. The school's pupil population was derived directly from the area in which it was situated and also received large numbers of children excluded from other schools. School C was under local authority control. School D was situated in an area with the highest proportion of ethnic minority residents in the city and took its pupil population from this area and other areas from the center of the city. The school was well resourced, and its GCSE results had been steadily improving over the past few years. School D was a technology college, a new school with a technology bias. School E was situated near a large housing estate and had a very small pupil population because of falling rolls. The local population was mainly white and working class, and this was reflected in the pupil intake. The school had a very small mixedparentage pupil population. School E was maintained by government grants.

\section{Understanding Resistance}

The concept of resistance in relation to schooling has been employed by a number of writers keen to explore how specific groups of pupils negotiate and respond to their marginal positions in schools, while avoiding a determinist analysis of schools' ability to reproduce these social and cultural inequalities. The seminal work of Paul Willis attempted to interrogate the division between structure and agency that earlier social reproduction accounts had introduced. ${ }^{8}$ Suggesting that the resistance of the working-class males in his study acted to reinforce their social class position, Willis argued that this was a choice his participants actively made. In this way, he attempted to engage debate on the issue of structure and agency. However, Willis's work has been criticized as dualistic and determinist. ${ }^{9}$ It has been suggested that, though Willis wished to avoid a determinist analysis by giving the boys agency, he posited an image of working-class culture as oppressive. Though feminists attacked Willis's work for its overly romanticized view of working-class masculinity, their own work on female resistance also acted to cement the lives of their respondents in working-class culture, albeit through their respondents' own choosing. ${ }^{10}$

The term "resistance within accommodation" has been used by feminist researchers to suggest that young women strategically employ aspects of ex-

\footnotetext{
${ }^{8}$ Paul Willis, Learning to Labour: How Working Class Kids Get Working Class Jobs (Aldershot: Saxon House, 1977).

${ }^{9}$ Walker.

${ }^{10}$ Angela McRobbie, Feminism and Youth Culture from Jackie to Just Seventeen (London: Macmillan, 1991), and "Working Class Girls"; Anyon; Davies.
} 
aggerated femininity in schools, such as blushing and giggling with (male) teachers, in order to avoid work. In this way, it is argued that young women effect forms of resistance within the context of the classroom and the teacherpupil relationship. However, often the issue of what is specifically being resisted by pupils becomes more complex, and theorists assume that the exaggeration of femininity described above can be seen as a rejection of the norms of femininity. ${ }^{11}$ The problem relating to structure and agency within resistance theories was therefore closely related to their emphasis on social reproduction. Critics suggested that, though resistance theories were ideally placed to explore the pupils' responses to schooling, they continued to focus on students' rejection of social structures. ${ }^{12}$ As Mark McFadden has argued, "disadvantage and inequality of achievement at school is related more to the rejection of the curriculum and pedagogy encountered by students than to a conscious resistance to the dominant ideology of society." 13 Therefore, research on resistance has led to alternative interpretations of pupil responses to schooling. Some writers have argued that resistance to schooling is not restricted to that of working-class pupils and indeed that some resistance may not be particularly class based. ${ }^{14}$

Other research, particularly in the area of race, has shown that black pupils, particularly males, exhibit both proschool and antischool attitudes. ${ }^{15}$ This latter finding is particularly important as much educational research conducted on black pupils in British schools has focused on disaffection. ${ }^{16}$ Another important aspect not restricted to race, but which has certain racespecific connotations, is that contrary to the basic assumptions of earlier resistance theories, many pupils do not reject the concept of education itself but, rather, the authoritarian function of teachers and the form and content of the curriculum. ${ }^{17}$ Research has also indicated that many black pupils do recognize the value of education but reject the wider racialized and gendered discrimination that filters through into peers' and teachers' perceptions of their behavior. ${ }^{18}$ As McFadden suggests, it is also important to view pupils' resistances as a response to the nature of knowledge that they receive in schools. He suggests that "students from certain kinds of background have

${ }^{11}$ Gerwirz.

${ }^{12}$ Ronald G. Sultana, "Transition Education, Student Contestation and the Production of Meaning: Possibilities and Limitations of Resistance Theories," British Journal of Sociology of Education 10, no. 3 (1989): 287-309.

${ }^{13}$ McFadden (n. 1 above), p. 296.

${ }^{14}$ Paul Aggleton, Rebels without a Cause: Middle Class Youth and the Transition from School to Work (London: Falmer, 1987); R. Meyenn, "School Girls" Peer Groups," in Pupil Strategies Explorations in the Sociology of the School, ed. Peter Woods (London: Croom Helm, 1980), pp. 108-42.

${ }^{15}$ Gillborn (n. 4 above); Sewell (n. 4 above).

${ }^{16}$ P. Harrell, "Do Teachers Discriminate? Reactions to Pupil Behavior," Sociology 29, no. 1 (1995): 59-73; Mac an Ghaill, Young, Gifted and Black (n. 3 above); Cashmore and Troyna (n. 7 above).

${ }^{17}$ Mac an Ghaill, The Making of Men (n. 3 above).

${ }^{18}$ Mary Fuller, "Young, Female and Black," in Cashmore and Troyna, eds., pp. 89-99. 
experiences of schooling which restrict their opportunity to extend their knowledge. The response to this form of schooling for many students is to resist it. What students are constantly rejecting, or sometimes at best, merely complying with regardless of class, gender, race and ethnicity, is schooling which depowers them." ${ }^{19}$ Research on race and resistance within schooling has been subject to criticism, which suggests that it is difficult both to distinguish between pupils' resistance and simple messing about and to prove empirically the existence of the teacher racism against which the majority of antischool black pupils resist. ${ }^{20}$ In a similar form to the criticism leveled at feminist theorizing of resistance within accommodation, the nature of the criticism directed at much research on race has suggested that black pupils merely reinforce dominant racialized stereotypes. ${ }^{21}$ For example, theorists on race and educational inequality have suggested that black pupils exhibit particular forms of speech, ways of walking, and, more recently, types of dress that are indicative of pupil resistance. ${ }^{22}$ Peter Foster, Roger Gomm, and Martin Hammersley argue that these explanations of pupil behavior are culturally essentialist, as reducing forms of behavior to race ignores the effect of class and gender on behavior. ${ }^{23}$ Foster et al. use this critique to suggest that it is difficult to establish that teachers act on cultural differences between themselves (as white) and their ethnic minority pupils. However, these criticisms fail to acknowledge that the varying types of resistance and contestation that occur in schools relate quite clearly to the racialized, gendered, and classspecific backgrounds of the pupils exhibiting them.

Theories of the intersection of race, class, and gender have shown distinct shifts in recent years. For example, marxism traditionally has not coped well with the complexities of theorizing racism. Increasingly, class analysis has, however, attempted to encompass political movements incorporating race and gender. ${ }^{24}$ Also, varying cultural forms have been incorporated into racial discourse. Indeed, it can be suggested that contemporary racism is increasingly focused on the cultural characteristics of specific groups, with the emphasis on difference. ${ }^{25}$ This has been shown in the work of Cecile Wright, John Eggleston, David Dunn, and Madju Anjali, where differences in teacher perceptions of African Caribbean and Asian pupils were revealed. ${ }^{26}$

${ }^{19}$ McFadden, p. 298.

${ }^{20}$ Gerwirz (n. 6 above); Peter Foster, "Case Still Not Proven: A Reply to Cecile Wright," British Educational Research Journal 12, no. 2 (1990): 165-70; Hammersley and Gomm (n. 5 above).

21 Gerwirz.

${ }^{22} \mathrm{Mac}$ an Ghaill, Young, Gifted and Black; Gillborn; Sewell.

${ }^{23}$ Foster et al. (n. 5 above).

${ }^{24}$ John Solomos and Les Back, Racism and Society (London: Macmillan, 1996).

${ }^{25}$ Stuart Hall, "New Ethnicities," in "Race", Culture and Difference, ed. James Donald and Ali Rattansi (London: Sage, 1992) pp. 252-59; Avtar Brah, "Difference, Diversity and Differentiation," in ibid., pp. 126-45.

${ }^{26}$ Wright et al. (n. 4 above). 
Pupils bring into schools their racialized and gendered positions, and these interact with their dispositions toward power. Pierre Bourdieu has suggested that pupils have a constantly reformulated set of dispositions toward power primarily rooted in social class. ${ }^{27}$ Race and class are inextricably intertwined in questions of how pupils are disposed to the power relations they experience in schooling. How race defines the educational experience is clearly connected to class background and is also defined in opposition to the predominantly white middle-class background of education professionals.

Having said this, race alone may influence the experiences of pupils in school. Research by Eric Horvat has shown that race in itself is a powerful influence in shaping school experiences. The point is also made that "often, this racial influence functions most effectively as a marker of class membership and position." 28 Other studies also argue for the interrelation of race and gender in the exploration of black experience. ${ }^{29}$ Some black feminists reject subsuming constraints of race within those of gender when exploring the experiences of black pupils. It has been argued that "black women cannot afford to look at our experience of Britain's education system merely from our perspective as women: this would be to over simplify the realities we face in the classroom. For black schoolgirls, sexism has, it is true, played an insidious role in our lives. It has influenced our already limited career choices and has scarred our already tarnished self-image. But it is racism which has determined the schools we can attend and the quality of the education we received in them." ${ }^{30}$ The complex ways in which gender and race intersect in the experiences of black pupils requires more examination. The gendered differences between black pupils has indeed been used to explain the differing adaptations of pupils and rates of academic achievement. ${ }^{31}$

As will be shown below in the accounts of the young people interviewed for the study, resistances were often located in pupils' wider racialized and gendered positions. Forms of speech, dress, and ways of walking are often indicative of displaced contestations or resistances, ${ }^{32}$ and these expressions hold greater cultural currency when used in an area (school) where black pupils are in a numerical and power-related minority.

${ }^{27}$ Bourdieu and Passeron (n. 2 above).

${ }^{28}$ Eric Horvat, "Structure, Standpoint and Practices: The Construction of Meaning of the Boundaries of Blackness for African Caribbean Female High School Services in the College Choice Process" (paper presented at the Annual Conference of the American Educational Research Association, San Francisco, March 21-28, 1997), p. 13.

${ }^{29}$ Amina Mama, Beyond the Masks: Race, Gender and Subjectivity (London: Routledge, 1995).

${ }^{30}$ Beverley Bryan, Stella Dadzie, and Suzanne Scafe, Heart of the Race (London: Virago, 1985), p. 58.

${ }^{31}$ Peter Woods, The Happiest Days? How Pupils Cope with School (London: Falmer, 1990); Heidi Mirza, Young, Female and Black (London: Routledge, 1992); David Gillborn and Caroline Gipps, Recent Research on the Achievement of Ethnic Minority Pupils (London: HMSO, 1996).

${ }^{32}$ Aggleton (n. 14 above). 
Though it remains important for a study of pupils' schooling experiences to explore whether they respond in resistant ways, there are certain issues that must be addressed in order to theorize these responses effectively. Resistance theorists have been criticized for "launching too readily into optimism without sufficiently articulating the constraints which limit and subvert the transformative potential of resistance. ${ }^{n 3}$ The debate is ongoing as to whether resistance to schooling, embedded within antischool attitudes, can actually effect change. However, if indeed pupils do resist the practice of knowledge production that takes place in schools, particularly where they feel that this knowledge does not reflect them culturally or experientially, the transformative nature of their resistance is problematized when they cut themselves off from gaining any form of knowledge. In Tony Sewell's study of the conformists and rebels, he suggests that though in some cases pupils may reject the function of schooling and the attendant knowledge that schools offer them, they do not reject the power of knowledge. ${ }^{34}$ For some black pupils, knowledge is sought from black communities, as they may feel that it is only within this sphere that they are adequately culturally and experientially reflected. They thus feel culturally distant from school. Sewell suggests, therefore, that these pupils believe that "knowledge can be used for collective action and the eventual betterment of the condition of black people. It is proof that students in this category do not close off the possibility of pursuing an emancipatory relationship between knowledge and dissent. ${ }^{{ }^{35}}$ Therefore, knowledge can encourage emancipatory dissent. However, Sewell suggests that the hedonists who, like Willis's subjects, rejected all forms of mental labor have cut themselves off from the emancipatory possibilities that arise out of gaining forms of knowledge. ${ }^{36}$ In this way, by rejecting the pursuit of all forms of self-knowledge, both within and outside of school, transformative possibilities are limited. It thus becomes difficult to theorize the behaviors and attitudes of these pupils as resistant. It is therefore important to acknowledge that the responses of all children to schooling are multiple and that not all oppositional behavior can be theorized as resistant. It is also important to identify what it is that is being resisted. However, this is not to suggest that the behaviors of Sewell's hedonists were simply reactionary, as their responses to schooling did not exist in isolation of others' responses to them. ${ }^{37}$ The work of Paul Aggleton has been important in differentiating between intent and outcome in relation to pupil responses to schooling. ${ }^{38}$

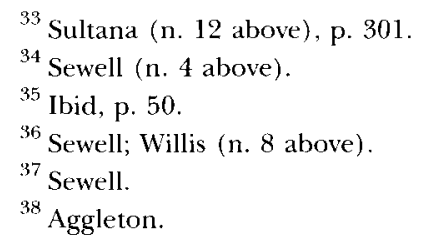


This would suggest that rather than viewing the behaviors of Willis's subjects (and hence also the hedonists in Sewell's study) as indicative of a rejection of mental labor, instead the young males were challenging principles of control within the school. ${ }^{39}$ Aggleton argues that it is necessary to differentiate between challenges against wider societal power relations and more localized principles of control, such as those occurring within schools. ${ }^{40}$ In this way it is possible to identify behaviors as resistant or contested. Additionally in differentiating between intent and outcome, it becomes possible to view the contestations of black pupils against specific processes within schools as having more resistant outcomes, in that often their responses are located within wider racialized discourses.

This discussion leads us to summarize a number of issues. First, if resistance is identified, what is being resisted? The suggestion is that it is a rejection of the curriculum and teaching-learning process encountered by pupils. The interaction between pupils and teachers takes the form of a struggle over the nature of knowledge, culture, and social practices. There is a resistance to the practice of the production of knowledge in schools particularly when neither the content nor the method reflects the pupils culturally. This rejection is primarily class based-that is, mainly a working-class hostility toward a white middle-class knowledge and education system. Working-class pupils seem to constantly reject schooling, as it does not lead to their empowerment. This often seems to be irrespective of race and gender. Of course, not all individual behaviors can be easily categorized as resistance. We have seen that some pupils appear to reject the pursuit of all forms of knowledge, and thus there are a variety of pupil responses. Not all oppositional behavior can be seen as resistance. It is difficult to distinguish between resistance to schooling and the rejection of knowledge. What is mostly being resisted are the mechanisms of control and knowledge production in schools. The resistance of pupils tends to be concentrated in this sphere rather than extended to contesting wider relations of power.

Second, the class-specific forms of resistance, described here and identified by others, interact with the social relations of race and gender. The concepts of resistance and contestation in relation to schooling need to be examined in relation to how specific groups of pupils respond to their positions. Hence, resistance strategies are likely to vary. As mentioned earlier, female pupils employ aspects of exaggerated femininity to avoid work. Different pupil groups exhibit both proschool and antischool attitudes. Black pupils respond to their racialization in the education process through disaffection. They do not however, as identified earlier, reject the idea of education.

The disaffection and contestation come more from the authoritarian role

\footnotetext{
${ }^{39}$ Willis; Sewell; Aggleton.

${ }^{40}$ Aggleton, p. 12.
} 
of teachers than from the form and content of the curriculum. Black pupils reject and contest the discrimination they perceive and the (mis) perceptions of their behavior by teachers. Black pupils feel culturally distant from school but are aware of the positive benefits of knowledge. What black pupils are contesting are specific school processes, in order to increase the personal space within which they can act. The outcomes appear as resistance to existing power structures. Contestations can take the form of protest at the form of interaction with teachers and so be aimed at weakening teachers' control of how knowledge is organized. Resistance is more likely to be directed as a challenge to the relations of power involved in schooling.

Clearly, the added focus on school exclusion, and the power embedded within it as one of an educational institution's most important sanctions, will provide an additional emphasis on the nature of the power struggle between pupils and teachers within schools. With these theoretical considerations in mind, it is now possible to explore the resistant possibilities within pupils' responses to schooling.

\section{The Effect of Sanctions on Teacher-Pupil Relationships}

The study on which this article is based has explored the nature and aftereffects of school exclusions and sanctions on young black, Asian, and white pupils. It has looked at processes that may lead to sanctions within the five schools. Of particular interest were the experiences of twelve black young people who have been permanently excluded from school. An important aspect of the experience of school sanctions, and one that is important to an analysis of pupils' resistance and contestation, relates to the issue of power. Within the school environment, relationships between pupils and teachers are structured on the basis of power and powerlessness. Resistance theories have often been criticized for assuming these relationships are unidirectional by placing students and teachers within predictable power positions. ${ }^{41}$ Taken from interviews of four pupils from two of the schools researched in the study, the following accounts illustrate how pupils use forms of resistance or contestation to negotiate the form that their relationships with teachers will take. Much resistance was used to subvert the traditional relationship of teacher as powerful, student as powerless. However, the power that teachers have to impose various school sanctions on pupils, culminating in school exclusion, adds a further dimension to the pupils' resistance. Contrary to the teachers' perceptions, these pupils did not exhibit antieducation sentiments. Rather, the pupils' responses were situated in their wider racial and gendered positions. Their responses reflect their perceptions of the effect of schooling on themselves as black males or black females. Additionally, in similar ways to the macho boys in Martin Mac an Ghaill's study, the pupils' resistance was

\footnotetext{
${ }^{41}$ Mac an Ghaill, The Making of Men (n. 3 above).
} 
a response to the domination, alienation, and infantilism they experienced. ${ }^{42}$ This was not as a result of being situated in lower sets, as Mac an Ghaill suggests of his respondents, but related to the threat of school sanction and permanent exclusion, which, under present education policy conditions, is continuously reinforced in schools. ${ }^{43}$

\section{Racializing Resistance}

We now address ourselves to how the interplay of racialized and gendered discourses reveal themselves in pupils, and how they interact with each other in the experience of schooling. The most pertinent examples to illustrate these conceptual issues emanate from school $\mathrm{A}$, which was situated in the middle of a fairly wealthy suburb in the city and performed very well within the area of the education authority in terms of the GCSE grades obtained. The majority of the pupil population was drawn from the immediate area, and therefore many of the pupils came from professional families. There was a small, but increasing black and Asian population, both in the area and the school. However, these pupils were perceived as being highly visible by many of the teachers. Black pupils were aware of their numerical minority status within the school and often grouped themselves together.

Alex, age 14, was part of a larger group of black males and females in years 9 and 10, and his response to the school was one of irritation:

Alex: I don't like [my Dramamy Drama] teacher. He picks on you. Like if you've got a bad reputation then he'll try and pick on you. If someone else was talking and so were you, they'd point out you . . . cause in the first week of school, when I was in Year 7, I got done on a [school] trip cause I was running off. And then ever since then, the teachers have not liked me because they thought I was a troublemaker.

Researcher: What sort of things do you get into trouble for?

Alex: I've been put on report for answering back and being cheeky.

Researcher: What makes you answer back?

Alex: Because they be cheeky too, they think they can be cheeky too and then you've got to stand there and take all the cheekiness what they say to you.

Researcher: And you don't want to stand there?

Alex: $\mathrm{No} !^{44}$

Alex was concerned about teachers who consistently brought up the past

42 Ibid, pp. 15, 57.

${ }^{43}$ Ibid., p. 15; E. Blyth and J. Milner, Exclusion from School: Inter-professional Issues for Policy and Practice (London: Routledge, 1996); Cecile Wright, Debbie Weekes, and Alex McGlaughlin, Race, Class and Gender in Exclusion from School (London: Falmer, 2000).

44 Taped interview conducted in school A, 1998, transcript 5, p. 3. For all transcribed interview quotations used in this article, ellipsis dots indicate deleted portions of transcript, italics indicate the speaker's emphasis, and square brackets indicate clarifications added by the authors. 
whenever they spoke to him, as it did not allow him to move beyond the conflictual relationship that existed between him and some of his teachers. His response is to challenge teachers verbally through using cheekiness, a strategy that has been theorized by many researchers of pupils' disaffection and subculture.$^{45}$ It is also used here by Alex in order to emphasize that he, as a pupil, can respond to a teacher on equal terms. Therefore, if cheekiness is worthy of school sanction when used by a pupil, it can also be condemned by pupils when used by teachers. In this sense Alex contests rather than resists teacher power. His response is further related to the powers embedded within the use of school sanction.

Though Alex had never experienced a school exclusion, he had been subject to a process of labeling, ${ }^{46}$ and his form tutor and head of year perceived him to be of some concern to the school. Therefore, his rejection of teacher power was further situated in their use of the threat of sanction. As Alex remarked, "Cause sometimes they just say you've been into trouble before so we're going to take it harder on you this time, and then the next we'll go harder and next time we'll go harder, just so they can prove a point." ${ }^{37}$ Alex recognized that he was high-spirited and often talked and messed about with friends in the classroom. However, he suggests here that sanctions may be used excessively by the school in order to prove the point that it has the ability to exert various forms of control over students. Therefore, at the base of many of the pupils' contestations, was the authoritarianism embedded within the ethos of schools.

Alex's experience was further mediated by his racial background, though he did not articulate this himself. Rather, his membership in a group of black male friends in the school affected teachers' perceptions of him. The group began to give teachers cause for concern:

I have noticed that we have . . . the West Indian groups of lads grouping together as black kids and running around. I say running because they are ever so gregarious . . . of course you get white kids but they don't seem to be . . . they [black pupils] are always singing and dancing and they're much more physically expressive. Now that in itself makes them noticed more, and they're really keen on developing an identity. And there's a special uniform that they wear and if they can possibly help it, they'll get it into school. . . But when they are walking around with scarves across their face, with all of them [faces] hidden. That's fine, that's brilliant. Come into the classroom, coats off and sit down, but they'll bring it into the classroom. And we've got one or two of these groups with strong leaders who are actually coming out with the racist thing. Like it's because I'm black that you're doing this. And that really irritates me because it's not, it's because they're not taking their bloody scarves off. ${ }^{48}$

\footnotetext{
${ }^{45}$ Willis (n. 8 above); Mac an Ghaill, Young, Gifted and Black (n. 3 above); Gillborn (n. 4 above); Wright et al. (n. 4 above).

${ }^{46}$ Mac an Ghaill, Young, Gifted and Black.

${ }^{47}$ Taped interview conducted at school A, 1998, transcript 5, p. 7.

${ }^{48}$ Teacher, taped interview conducted at school A, 1998, transcript 10, p. 5.
} 
Scarves were, however, worn by a large number of black, white, and Asian pupils in the school, often pulled up over mouths and noses. There is an assumption that Alex and his friends who are part of this group sing, dance, and wear specific clothing because of a natural disposition. The teachers who express concern have constructed the wearing of scarves in this way as a racial signifier, because of the high visibility of the group of young males and females who may dress in similar ways. The clothes worn by these pupils were also worn by other black pupils in the remaining four schools studied and in the various communities in which the pupils lived. The wearing of specific coats, hats, and scarves was indicative of a racialized identity, which was also drawn on by white pupils.

However, much of the above teacher's comments on this identity related to the group's separateness, which was perceived by the teachers as an act of resistance, whereas mixture was seen as more conducive to learning:

To be honest, we've got some black kids, not lots, and they seem, not all, but a lot of them, seem to hang around with their own peers within a group. They have their own subculture. Try to bend the uniform so they can dress in whatever way and so when they're together, some of them don't perform as well as they should do, because, yet again, they want to be one of the boys. And they're bright, there's no problem in that respect, it's just they want to be different-that's understandable perhaps-but it does affect the way they learn. . . . They do group together, they want to have their own personal identity and that's how the uniform changes a bit. They wear woolly hats and we say no woolly hats in school etc. and you have to keep on and on. . . I suppose if they hang around together, it can be a bit intimidating perhaps for other kids. You know, we've got some other black kids, lads particularly, who will just do their own thing. . . . Hang around with everybody else and just, y'know, mix in. ${ }^{49}$

The assumption here is that black children who achieve well have managed to integrate and that those who do not integrate underachieve because of the racial identity that is fostered within the group. One black female member of the group was known by the researchers to be aware of the way that she and others were perceived, and it is likely that other members of the group were also aware. This characterized the group's response to the teachers and the sanctions used. They perceived the involvement of racism in some teachers' interactions with them, because their friendship groups were seen by these teachers in racially negative terms. Grouping together in this way, therefore, served racialized identity functions and also acted as a way of resisting the desire for integration that the teachers articulated. This was a challenge both to teachers' attempts to control friendship groupings and to the wider social relations that position the grouping of racialized individuals together as separatist. However, for some pupils it may be easier to submit to the forms

${ }^{49}$ Teacher, taped interview conducted at school A, 1998, transcript 10, p. 8. 
of teacher control within schools, because of the implicit power imbalance embedded within the teacher-pupil relationship.

For Johnny, a black, year-11 pupil who had moved to the school at the start of the year from another city, the form of pupil contestation he employed at his former school had not proved satisfactory for him, and it is here that the transformative possibilities of pupil resistance come into question. Johnny had previously lived in an area where the British National Party was very active, and because his father had been fairly well known, Johnny had been subject to a variety of physical racial attacks. This had become reflected in his behavior in school, where Johnny felt teachers were not supportive: "A lot of teachers, sometimes they're scared of black boys. My form tutor was scared of me, you could tell. I was probably big for my age and . . . he wouldn't tell me to sit down and take my jacket off. He'd wait till I'd do it. He wouldn't ask for homework. If he told me something and I disagreed with it, he'd back down straight away. And I took that to my advantage." Johnny had employed forms of resistance in school, answering back and fulfilling what he felt to be teacher expectations of black male behavior. His actions, however, were also related to his experience of racial violence outside of school. Though he was aware that similar stereotypes were in use at school A, Johnny no longer wished to contest them: "Over here, every black person is a rude boy, if they dress a certain way. That's how they [teachers] see them. Here it's just more blatant, probably because they haven't got much black people in the school. Because when I came here I had long plaits and I kept hearing people say to me oh he's a rude boy. So I cut it all off. Just to give me a new image and start afresh." 51

\section{Gendered Responses}

School B was situated near a fairly large low-income housing estate in the center of the city. It took excluded pupils from a nearby technology school and had a greater number of black and Asian pupils than school A. There was also a greater focus on race illustrated by displays on the walls. The school had recently introduced a change in classroom discipline that some of the pupils felt had had an adverse effect on the experiences of black pupils. The extracts from interviews conducted at school B illustrate succinctly the gendered responses explored in this section.

Chantel, a year-10 pupil of mixed parentage, felt that racism was endemic within the school and was a member of a group of black pupils who shared her sentiments.

Chantel: Do you know how many black pupils he's [the head teacher's] excluded? Seventeen last time I looked. I was the first black girl to be excluded. It was all

${ }^{50}$ Taped interview conducted at school A, 1998, transcript 2, p. 8 .

51 Taped interview conducted at school A, 1998, transcript 2, p. 10 
boys and then we . . . it was like we was putting up a stubborn way. If he spoke to us we would just walk off and kiss our teeth after him. He started excluding white people to style it out. He said we're going to kick all the clowns out. . . .

Researcher: How have you all reacted to that?

Chantel: Bad. Every time he speaks to us we don't listen to him. It makes us turn bad if you know what I mean. It like causes. . . . [I mean] he calls everyone a clown and only excludes black people. He must think we'll react in a [certain] way to that. We're bound to react in a bad way.

Researcher: Are you saying you think he does it on purpose?

Chantel: Yeah. You know what makes me mad? When I can see racism staring in my face and I can see him treating the next [white] people different . . . and I just flip and just cuss him off. And it's not my fault, well it is, I shouldn't cuss him off. I've got a bad temper and I've been told to control it. So I've tried to control it but then he says something worse [which] makes me flip even more. ${ }^{, 52}$

Chantel and the other black pupils of whom she has spoken have effected forms of resistance against the threat of school exclusion employed by the head teacher. Though their response is related to the localized principle of control embedded within the school, it is resistant rather than contesting because, in a similar way to Johnny above, it is a racialized response. They have responded to the way that school exclusion, and the tightening up of discipline, has been racialized by the head teacher. In responding to such processes of racialization, they have employed racial signifiers (such as kissing their teeth),$^{53}$ which have similar effects to the wearing of woolly hats and scarves by black pupils.

However, the use of resistance for Chantel has specific effects on her:

She's [the teacher has] got a big problem. She said something racist to me, I can't remember the words but I reported it and [the head teacher] says you'll find that Miss Beverage is not racist because she is in the black bullying group. [My Science teacher] said [to us] didn't they bring you up with manners where you two come from? We tried to get him done, but we swore at him. Sometimes we just go in the [section 11] room and cry our eyes out. We just cry, because we report it, report it and no one does anything. So they wonder why we turn bad. [they say] the best thing to do with Chantel is to chuck her out before the lesson starts. I go home and I feel like. . . . ${ }^{54}$

The process of racializing resistance has similar effects on Chantel's black female friends:

Me and Donna were in assembly and this white boy was talking. Miss Beverage came up [to us] and said "you two, out now!" Me and Donna looked at each other and said "what are you talking about?" and then she said we were talking and we didn't even say one word. Mr Mills [head teacher] sent us to his office, gave us a

\footnotetext{
${ }^{52}$ Taped interview conducted at school B, 1999, transcript 20, p. 9.

${ }^{53}$ This is a sucking sound used as a gesture of disdain or contempt.

${ }^{54}$ Taped interview conducted at school B, 1999, transcript 20, p. 12.
} 
detention and everything. But we wouldn't go because we didn't do nothing and we didn't say anything. So anyway they were saying that we were talking and everything and we just said "what's your problem? What's your problem with black people?" and [Mr Mills] said "Are you trying to say we are racist?" We says "No." We're just standing up like fools saying it for no reason! And Donna kissed her teeth. So he says "Don't think I don't know what that means" . . . and he started shouting get out of this school, you are going to be excluded. [We said] . . ."we haven't done anything wrong." Then Miss Beverage came out and we had two teachers shouting at us. We got punished. Donna got excluded and she had to apologize-for nothing, for nothing! Donna started crying when she walked out of his office because she was saying sorry for no reason ${ }^{5,5}$

Both Donna and Chantel have reacted to their powerless status in the pupilteacher-school relationship. It appears that the powerlessness embedded within their inability to convince the two teachers that they had not in fact been talking in assembly engenders an almost helpless feeling. Importantly, however, they avoid displaying this helplessness to the teachers who are sanctioning them. Chantel goes into a separate room, and Donna waited until she had left the head teacher's office. Thus, they attempt to extract power from the interactions with teachers at every available opportunity by verbally challenging decisions that they feel to be illegitimate.

\section{Conclusion}

Though this article has illustrated a variety of ways in which pupils respond to the use and threat of school sanctions by teachers, this is not to suggest that all pupils interviewed within the study are exhibiting forms of resistance. For many, their responses to schooling were often similar to the displaced contestations of other wider oppressions experienced elsewhere, as outlined by Aggleton. ${ }^{56}$ Some of the white working-class males interviewed, but not discussed here, rejected the importance of schooling because they considered it to be irrelevant to their desire to leave school and learn a trade in the army. However, the experience of school exclusion, or the process through which schools used it as a means of controlling pupils, influenced the nature of their responses. The experience of the power imbalance between pupils and teachers discussed above has been related to the exercise of power embedded within the use of school sanctions. However, it was also mediated through their racialized positions, which allowed their contestations of the inappropriate use and threat of sanctions to have more race-specific resistant effects. The pupils interviewed did not hold antieducation sentiments, and indeed many of them were of average-to-high academic ability. Thus, they were not contesting the value of schooling, nor were their grievances directed toward the near inevitability of unemployment at the end of their school

\footnotetext{
55 Taped interview conducted at school B, 1999, transcript 2, p. 14

${ }^{56}$ Aggleton (n. 14 above).
} 
careers. This, however, does not negate the social reproductive capabilities of educational institutions, as resistance to schooling can have certain classspecific and racialized effects in terms of pupils' abilities to gain employment. ${ }^{57}$ Rather, they rejected their powerless positions as pupils within schools, which was reflected in their experiences of various controlling sanctions. For some, this powerlessness was extended by their racial positions.

It is important, however, to recognize the limitations of theorizing resistance for pupils in schools, especially where it is perceived as disruption by teachers. There is also the danger that forms of behavior-identity, such as those demonstrated by the group of black pupils in school A, become racialized by others in ways that are not positive or transformative.

This article has contributed to the debate and evidence relating pupils' behavior and discourses to their racialized position. There is a link between forms of contestation and resistance to cultural differences. The theoretical debate initiated by Foster and others rejects all current research findings pointing to racialized and gendered positions. However, in a sense, Foster does accept a racialized position for black pupils: "I think that there may be a general tendency for Afro-Caribbean students on average to be less well behaved in schools." ${ }^{2}$ However, he denies that the schooling process and teachers are implicated in this racialization of behavior. Rather, he locates the source of this as being outside the school. This serves to pathologize black pupils by emphasizing cultural difference. The work of Foster and others thus denies the racialized lived experiences of black pupils.

Similarly, education policy over the past 15 years has deemphasized racialized positions as a significant factor in the education process. ${ }^{59}$ However, the context of school exclusion and sanction has become increasingly racialized in view of the disproportionate frequency of exclusions of black pupils. ${ }^{60}$ Policy has exacerbated the problems of exclusion: there has been a reinforcement of the concept of the ideal pupil by emphasizing cost efficiency, examination performance, and marketization in schools. Therefore, pupils are seen as costly in financial terms and in terms of league table performance, that is, their position in relation to other schools as measured by examination performance. In this context and climate, schools may be less likely to see their role as being inclusive-that is, education for and of all. They may see some pupil groups as a liability. Therefore, the current educational climate, with its emphasis on raising standards and improving discipline, will continue to extend the powers of schools to apply greater sanctions to pupils.

${ }^{57}$ McFadden (n. 1 above).

${ }^{58}$ Foster (n. 20 above), p. 23.

${ }^{59}$ David Gillborn, "Racism and Reform: New Ethnicities and Inequalities," British Educational Research Joumal 23, no. 3 (1997): 348-56.

60 "Blacks 15 Times More Likely to Be Excluded," Times Education Supplement (London) (December 1998), pp. 1, 11. 
Therefore, within the area of school sanction, the use of various strategies by pupils to contest the increasing disciplinary control to which they are subject cannot be dismissed as reactionary and, hence, politically limited. Rather, as Lynn Davies suggests, "School resistance [should] be capitalised upon ... . to provide [pupils] with a recognition of their own power which they may be able to transfer to other forms of efficacy in their lives." ${ }^{361}$

${ }^{61}$ Davies (n. 4 above), p. 39. 
Scarves were, however, worn by a large number of black, white, and Asian pupils in the school, often pulled up over mouths and noses. There is an assumption that Alex and his friends who are part of this group sing, dance, and wear specific clothing because of a natural disposition. The teachers who express concern have constructed the wearing of scarves in this way as a racial signifier, because of the high visibility of the group of young males and females who may dress in similar ways. The clothes worn by these pupils were also worn by other black pupils in the remaining four schools studied and in the various communities in which the pupils lived. The wearing of specific coats, hats, and scarves was indicative of a racialized identity, which was also drawn on by white pupils.

However, much of the above teacher's comments on this identity related to the group's separateness, which was perceived by the teachers as an act of resistance, whereas mixture was seen as more conducive to learning:

To be honest, we've got some black kids, not lots, and they seem, not all, but a lot of them, seem to hang around with their own peers within a group. They have their own subculture. Try to bend the uniform so they can dress in whatever way and so when they're together, some of them don't perform as well as they should do, because, yet again, they want to be one of the boys. And they're bright, there's no problem in that respect, it's just they want to be different-that's understandable perhaps-but it does affect the way they learn. . . . They do group together, they want to have their own personal identity and that's how the uniform changes a bit. They wear woolly hats and we say no woolly hats in school etc. and you have to keep on and on. . . I suppose if they hang around together, it can be a bit intimidating perhaps for other kids. You know, we've got some other black kids, lads particularly, who will just do their own thing. . . . Hang around with everybody else and just, y'know, mix in. ${ }^{49}$

The assumption here is that black children who achieve well have managed to integrate and that those who do not integrate underachieve because of the racial identity that is fostered within the group. One black female member of the group was known by the researchers to be aware of the way that she and others were perceived, and it is likely that other members of the group were also aware. This characterized the group's response to the teachers and the sanctions used. They perceived the involvement of racism in some teachers' interactions with them, because their friendship groups were seen by these teachers in racially negative terms. Grouping together in this way, therefore, served racialized identity functions and also acted as a way of resisting the desire for integration that the teachers articulated. This was a challenge both to teachers' attempts to control friendship groupings and to the wider social relations that position the grouping of racialized individuals together as separatist. However, for some pupils it may be easier to submit to the forms

${ }^{49}$ Teacher, taped interview conducted at school A, 1998, transcript 10, p. 8. 